\title{
超硬質エ具による耐熱合金の高速エンドミル加エ
}

\section{High Speed End Milling of Heat-resistant Alloy by Superhard Cutting Tool}

$\bigcirc$ 学 鈴木 健士朗 ${ }^{* 1}$, 細川 晃 ${ }^{* 2}$, 長嶋 拓海 ${ }^{* 3}$, 小谷野 智広*2, 古本 達明 ${ }^{* 2}$, 橋本 洋平*2

Kenshiro SUZUKI ${ }^{* 1}$, Akira HOSOKAWA ${ }^{* 2}$, Takumi NAGASHIMA*3

Tomohiro KOYANO ${ }^{* 2}$, Tatsuaki FURUMOTO ${ }^{* 2}$, Yohei HASHIMOTO*2

*1 金沢大学大学院 Graduate school of Natural Science \& Technology, Kanazawa University

*2 金沢大学 Kanazawa University

*3 アイシン精機(株) Aisin Seiki Co. Ltd.

Key Words : End milling, Cutting temperature, CBN, Diamond, Ni-based alloy

\section{1. 緒 言}

$\mathrm{Ti}$ 合金や Ni 基合金などの而熱合金は航空機用エンジンなどに用いられているが，その低い熱伝導率や高強度 などに起因して切削温度が高く, 而熱性のコーティング工具やセラミック工具による湿式切削においても工具損 耗が大きい，そこで本研究は，硬質でかつ熱伝導率の大きい CBN およびダイヤモンドといった超硬質工具を用 いて Ti-6Al-4V および Inconel718 の乾式高速エンドミル加工を行い，その適用性を検討している.

\section{2. 実験方法および実験条件}

実験は乾式エンドミル加工を行った．図 1 に示すように，工作物にあけた小孔 $(\phi 1.1 \mathrm{~mm})$ に光ファイバを挿入 し，切れ刃がファイバ前方を通過するときに逃げ面からふく射される赤外線を受光して温度を測定する(1). 使用 した工具は, CBN 焼結工具 (PCBN), バインダレス CBN 工具 (BL-CBN), ダイヤモンド焼結工具 $(\mathrm{PCD})$ および CVD 単結晶ダイヤモンド工具 (CVD-SCD)の 4 種類である(すくい角 $0^{\circ}$, チップブレーカなし).

\section{3. 実験結果}

図 2 に Inconel 718 を切削した場合の切削速度 $V_{\mathrm{c}}$ と工具逃げ面温度 $T_{\mathrm{f}}$ の関係を示す. Ti-6Al-4V を切削した場 合と異なり，工具温度は工具の熱伝導率と明確な関倸はみられず， $V_{\mathrm{c}}=800 \mathrm{~m} / \mathrm{min}$ において，CVD-SCD と BL$\mathrm{CBN}$ が 850 $880^{\circ} \mathrm{C}, \mathrm{PCBN}$ と PCD がおよそ $1000^{\circ} \mathrm{C}$ になった. 図 3 に工具温度が低い BL-CBN と CVD-SCD の切 りくず形態を示す $\left(V_{\mathrm{c}}=800 \mathrm{~m} / \mathrm{min}\right)$. BL-CBN ではすべての切削速度において, 図 3(a)のような理論切取形状に相 当した安定した切りくずが生成されているが，CVD-SCD ではやや不安定になっている．図は省略するが，BLCBN では顕著な工具摩耗もみられず, Inconel 718 の高速エンドミル加工に最も適していると考えられる.

\section{文献}

(1) Ueda, T., et al., “Temperature on Flank Face of Cut-ting Tool in High Speed Milling”, CIRP Annals, Vol. 50, Issue 1, pp. 37-40.

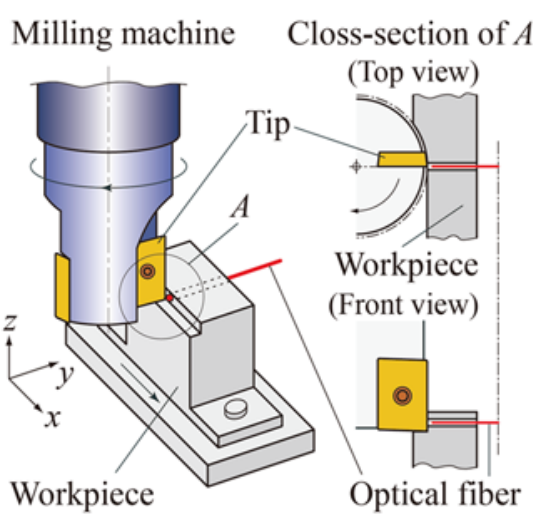

Fig. 1 Experimental setup

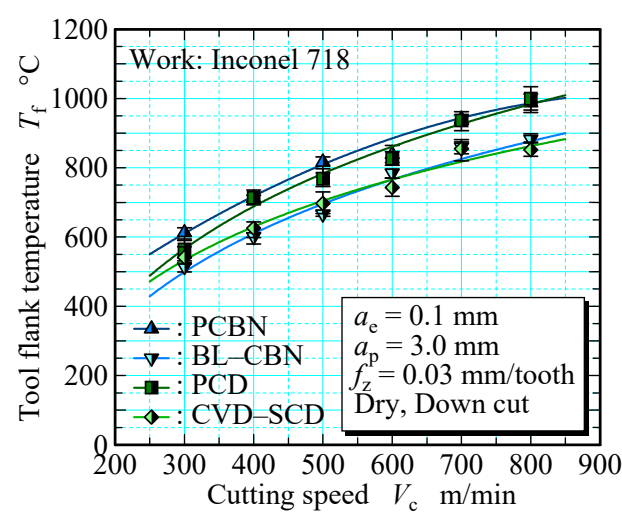

Fig. 2 Tool flank temperature vs. cutting speed
謝 辞

本研究の遂行にあたり, 切削 工具の提供をいただいた住 友電工ハードメタル(株に深 謝します。

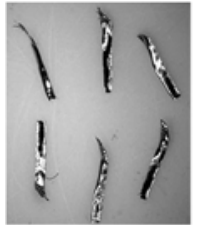

(a) BL-CBN

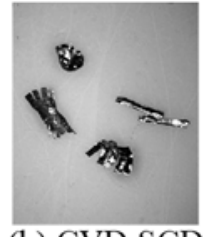

(b) CVD-SCD
Fig. 3 Chip morphology 